\title{
Haematological Traits and Serum Biochemistry of Grasscutters Fed Elephant Grass Supplemented with Concentrate
}

\author{
Gboshe Peter Noah $^{1,}$, Ebiloma Stella Osarenakhue ${ }^{2}$, Shettima Ibrahim ${ }^{3}$, Boyi Prince Ufedojo ${ }^{4}$, \\ Netala Jibrin ${ }^{5}$ \\ ${ }^{1}$ Department of Animal Science, Faculty of Agriculture and Forestry, Obubra Campus, Cross River University of Technology, Calabar, \\ Nigeria \\ ${ }^{2}$ Department of Forestry and Wildlife, Kogi State University, Anyigba, Nigeria \\ ${ }^{3}$ Department of Animal Science, Federal University, Kashere, Nigeria \\ ${ }^{4}$ Department of Animal Production, Kogi State University, Anyigba, Nigeria \\ ${ }^{5}$ Department of Food, Nutrition and Home Science, Kogi State University, Anyigba, Nigeria
}

Email address:

petergboshe72@gmail.com (G. P. Noah)

${ }^{*}$ Corresponding author

\section{To cite this article:}

Gboshe Peter Noah, Ebiloma Stella Osarenakhue, Shettima Ibrahim, Omata Sonia Blessing, Boyi Prince Ufedojo, Netala Jubrin. Haematological Traits and Serum Biochemistry of Grasscutters Fed Elephant Grass Supplemented with Concentrate. Animal and Veterinary Sciences. Special Issue: Current Topics in Reproductive Physiology and Assisted Reproductive Technologies in Farm and Wildlife Animals. Vol. 8, No. 1, 2020, pp. 29-35. doi: 10.11648/j.avs.20200801.14

Received: November 13, 2019; Accepted: January 28, 2020; Published: April 1, 2020

\begin{abstract}
This study was carried out to evaluate the haematological and serum biochemical indices of Grasscutters fed elephant grass supplemented with different levels of concentrate. A total of fifty grower Grasscutters were randomly assigned to 5 treatment groups of 10 Grasscutters each with 5 replicates with two animals serving as a replicate. The experimental treatments consisted of 1, 2, 3, 4 and 5 for 1, 3, 5, 7 and 9\% respectively of concentrate feed supplements which were served at their weekly live weight. The results showed that, except the haemoglobin and blood platelets, all others blood indices measured had no significant $(\mathrm{P}>0.05)$ effect. However, Packed cell volume (PCV) (41.61 -41.93\%), White blood cells-WBC $\left(2.50-2.55\left(\times 10^{3} / \mu \mathrm{l}\right)\right.$, red blood cells-RBC (4.95 - $\left.5.35 \times 10^{6} / \mu \mathrm{l}\right)$, mean corpuscular volume-MCV $(89.25-90.80 \mathrm{fl})$, Mean Corpuscular Haemoglobin-MCH (25.35 - 25.90 pg) and Mean corpuscular haemoglobin concentration MCHC (28.10 - 29.20 $\mathrm{g} / \mathrm{dl})$ and haemoglobin-Hb (12.07 $-12.55 \mathrm{~g} / \mathrm{dl})$. The results of the serum biological indices showed that total protein was not significantly affected except its fractions. Serum glucose, cholesterol, enzymes and ions except potassium were significantly $(\mathrm{P}<0.05)$ affected by the test, however these values were within the normal range for grasscutters when compared to other researchers. It was therefore concluded that, basal feed of elephant grass supplemented with concentrate can be fed without any adverse effect on the blood profile of grasscutters.
\end{abstract}

Keywords: Concentrate, Supplementation Regimes, Grasscutters, Haematology, Serum Biochemistry

\section{Introduction}

The popularity of grasscutter meat is the reason for the interest in the domestication of grasscutter for large scale farming and production of meat for human consumption [1]. The suitability of the meat and range of products obtainable from processing depends on the chemical composition of meat. The level of nutrition not only affects the growth of animals but the composition of their meats. Karikari and Nyameasem, [2] suggested that efficient production in captivity of grasscutter with high productivity require adequate nutrition. Though grasscutters are herbivorous animals and they grow rapidly on compounded feeds [3]. The domestication of grasscutter has not yet been perfectly 
established but when confined, should be fed with forages and concentrate [4]. Captive reared grasscutter are fed with forages and concentrates depending on the availability of the feed source, but the concentrates must be in low quantity to avoid a negative influence on the animal $[5,6]$.

Haematological observations provide valuable information about health of human and animals. According to Afolabi et al. [7], changes in haematological parameters are often used to determine health status of the body and to know the degree of environmental, nutritional and/or pathological stresses. Factors that affect blood like drugs, pathogenic organism or nutrition will certainly affect the entire body adversely or moderately in terms of health, growth, maintenance and reproduction [8)]. A readily available and fast means of assessing clinical and nutritional health status of animals on feeding trials may be the use of blood analysis, because ingestion of dietary components has measurable effects on blood composition. Maxwell et al. [9], Adamu et al. [10] observed that nutrition had significant effect on haematological values like park cell volume (PCV), haemoglobin $(\mathrm{Hb})$ and red blood cell (RBC). Togun et al. [11] reported that when the haematological values fall within the normal range reported for the animal, it is an indication that diets did not have any adverse effect on haematological parameters during the experimental period but when the values fall below the normal range, it is an indication of anaemia. White blood cell (WBC) roughly represents the immune status of the animals; when WBC (leucocytes) falls within the normal range, it indicated that feeding patterns do not affect the immune system; most immunological abnormalities observed in malnutrition are usually reversed with adequate adjustment to the quality of the feed [12]. According to Adekoya et al. [13], increase in neutrophils: lymphocyte ratio is a good indicator of stress which could be of nutritional origin. Serum parameters are important in the proper maintenance of the osmotic pressure between the circulating $\mathrm{pH}$ and the fluid in the tissue spaces so that exchange of materials between the blood and the cells could be facilitated. Moreover, these parameters contribute to the viscosity and maintenance of normal blood pressure and $\mathrm{pH}$ [14].

It was therefore, the aim of this study to assess the effect of feeding elephant grass supplemented with different levels of concentrate on the haematological and biochemical indices of grasscutters.

\section{Materials and Methods}

\subsection{Study Area}

The experiment was carried out at the Teaching and Research Farms of the Faculty of Agriculture and Forestry, Cross River State University of Technology (CRUTECH), Obubra, Cross River state, Nigeria. Obubra is located between longitude $8^{\circ}-9^{\circ} \mathrm{E}$ and Latitude $6^{\circ}-7^{\circ} \mathrm{N}$ of the equator. The mean annual rainfall of the area ranges from 500 to $1070 \mathrm{~mm}$, with a warm weather and ambient temperature of about $20^{\circ} \mathrm{C}-30^{\circ} \mathrm{C}$ Obubra is located along the banks of the Cross River in the Southern Guinea Agro-Ecological Zone of
Nigeria. Obubra is about $159 \mathrm{~km}$ from Calabar, the state capital of Cross River State of Nigeria.

\subsection{Experimental Diet}

The concentrate supplement was formulated to obtained $18 \%$ crude protein and Metabolizable energy of 2961.47 $\mathrm{kcal} / \mathrm{kg}$ with the ingredients as shown in Table 1 . This diet was served daily in their feeding trough at levels of 1, 3, 5, 7 and $9 \%$ of their live weekly body weight. The elephant grass (Pennesitum purpureum) was wilted overnight about 18 hours, chopped, weighed using a Camry top loading weighing scale and fed unrestricted in mangers to the grasscutters.

Table 1. Composition of concentrate feed.

\begin{tabular}{ll}
\hline Ingredients & \% \\
\hline Maize & 58.41 \\
Soybean meal & 27.59 \\
Rice offal & 10.00 \\
Bone meal & 3.00 \\
Vitamin-min-premix* & 0.50 \\
Common salt & 0.50 \\
Total Calculated composition & 100.00 \\
Crude Protein & 18.00 \\
Metabolizable Energy (/kcal/kg) & 2961.47 \\
Crude fibre (\%) & 6.97 \\
Calcium (\%) & 1.16 \\
Phosphorus (\%) & 0.89 \\
\hline
\end{tabular}

* Each $1 \mathrm{~kg}$ of vitamin/mineral premix manufactured by BEAUTS Co. Inc. Man, U.S.A., contains Vitamin A 220,000, Vitamin D 66,000, Vitamin E 44, 014; Vitamin K $88 \mathrm{mg}$; Vitamin B 12; $0.76 \mathrm{mg}$; Niacin $1122 \mathrm{mg}$, Calcium $27 \%$, Phosphorus $10 \%$, Iron $0.6 \%$, Zinc $0.35 \%$, manganese $0.25 \%$, Copper $0.06 \%$; Iodine $0.002 \%$, Cobalt 26 ppm, Selenium 4 pp. ME $=$ Metabolizable Energy

\subsection{Experimental Animals}

A total of fifty (50) weaned grasscutters between the ages of 3-4 months obtained from a local farmer in Ibadan were used for the feeding trial. The grasscutters were divided into groups of similar body weights and were randomly assigned to five treatments feeding regimes in a completely randomized design. There were five replicates in each treatment with two animals serving as a replicate. The animals were given elephant grass as basal feed ad libitum and formulated concentrate supplemented at a feeding regime of $1,3,5,7$, and $9 \%$ (for $\mathrm{T}_{1}, \mathrm{~T}_{2}, \mathrm{~T}_{3}, \mathrm{~T}_{4}$ and $\mathrm{T}_{5}$ respectively) of their weekly live body weight throughout the period of the experiment

\subsection{Determination of Haematological Indices}

At the end of the $24^{\text {th }}$ week of the study, the animals were slaughtered for carcass analysis between 6-8 am in the morning and blood was collected when the neck of the grasscutter was severed. Ten $(10 \mathrm{ml})$ each was collected from the animal. Five (5 $\mathrm{ml}$ ) of the blood was put in blood sample bottles containing 1 mg ethylene-diamine-tetra acetic acid (EDTA), an anticoagulant for haematological assay. Another $5 \mathrm{ml}$ of the blood was put in sterilized blood sample bottles, without anticoagulant, for serum biochemical assay. In order to isolate serum; the 
whole blood was put in a glass tube and allowed to stand for 2 hours at room temperature to clot. The clotted blood was then placed in a centrifuge which spins the blood at a high speed for 10 minutes at the rate of $2000 \mathrm{rpm}$ thereby causing the clot and the cellular parts of the blood to separate from the serum and sink to the bottom of the tube. The serum remained at the top of the tube and was collected for analysis. Serum is preferred for the estimation of the biochemical substances because many of these substances are present in different concentrations in the serum and the RBC (it is the concentration in the serum that changes in disease or abnormal condition) and therefore its analysis will aid diagnosis [15].

Hematological indices determined were red blood cell count (RBC) or erythrocyte count using the improved Neubaer Haemocytometer method Jain, [16], white blood cell count (WBC) or leucocyte count using the method of Schalm et al. [17], Haematocrit or packed cell volume (PCV) using Wintrobe's Microhaematocrit method Dacie and Lewis [18]) and haemoglobin ( $\mathrm{Hb})$ using Cyanomethaemoglobin method Kelly, [19]; others such as the Mean corpuscular volume (MCV), mean corpuscular haemoglobin $(\mathrm{MCH})$ and mean corpuscular haemoglobin concentration (MCHC) were determined using the procedure outlined by Jain, [16]

\subsection{Determination of Biochemical Indices}

Serum biochemical constituents determined were total protein and albumin using the Biuret method procedure of Smith [20] and globulin, which was obtained by difference between the total protein and albumin. Cholesterol was determined using an automatic device (HITACHI 902), ions using flame photometer and enzymes, Serum glutamic oxaloacetic transaminase (SGOT/AST) and serum glutamic pyruvate transaminase (SGPT/ALT) was determined using reagents kits.

\subsection{Data Analysis}

Data collected were subjected to analysis of variance (ANOVA) using MINITAB 16 statistical software and the means were separated using Fishers LSD method as contained in the statistical package.

\section{Results and Discussion}

\subsection{Proximate Composition of the Concentrate Feed Supplement and Elephant Grass}

The results of the proximate composition of the formulated diet and elephant grass used for the study are presented in Table 2. The crude protein content of the experimental diet analysed $(17.85 \%)$ was similar to the calculated value $(18 \%)$ and met the crude protein requirements $(18 \%)$ of growing grasscutters [21]. Elephant grass has low protein content of $8.18 \%$, high fibre content of $27.19 \%$ and ether extract content of $1.18 \%$, thus necessitating the use of formulated concentrate so as to improve their performance. The results of proximate analysis is similar to that of Onyeanusi et al. [22] and Wogar et al. [23] with some few variations that may be due to soil nutrients or period of harvest since these factors among others are known to affect the nutrients availability of forages.

Table 2. Proximate composition of elephant grass and concentrate supplement.

\begin{tabular}{|c|c|c|c|c|c|c|c|}
\hline Constituents Elephant grass & Dry matter & Crude protein & Crude fibre & Ether extract & Ash & NFE & ME/kcal/kg \\
\hline$\%$ composition & 34.30 & 9.25 & 31.00 & 1.17 & 9.28 & 49.30 & 2187.17 \\
\hline Concentrate & & & & & & & \\
\hline$\%$ composition & 86.98 & 17.85 & 5.07 & 3.20 & 10.12 & 50.74 & 2720.92 \\
\hline
\end{tabular}

\subsection{Haematological Parameters of Grasscutters Fed Different Levels of Concentrate Supplement}

The haematological data obtained from grasscutters fed concentrate supplement feeding regimes are presented in Table 3. The analysis of variance revealed no significant $(\mathrm{P}>0.05)$ difference in $\mathrm{RBC}$ between the treatment groups. The RBC value of $5.00-5.35 \times 10^{6} \mu 1$ obtained in this study are slightly lower than $8-10 \times 10^{6} \mu \mathrm{l}$, reported by Olomu et al. [24]; 6.9-7.7 x $10^{6} \mu 1$ reported by Bleyere et al. [24] and $12.36 \times 10^{6} \mu \mathrm{l}$ indicated for reared captive grasscutter (Ogunsami et al. [26]. Opara et al. [27] obtained 8.4-8.6 $10 \mathrm{x}$ $10^{6} \mu 1 \mathrm{RBC}$ for wild grasscutters.

Haemoglobin values obtained in this experiment was significant and were within the range of 9.7-14.7 $\mathrm{g} / \mathrm{dl}$ reported by Byanet et al. [28] for grasscutters reared in northern Nigeria. It is also within the range recorded (12.713-7 g/dl) by Bleyere et al. [25], who studied the period and repeatability of blood sampling in reared Grasscutters. This suggests that these feeding regimes in grasscutters did not impair nutrient availability so as to cause anaemic conditions and as the protein intake was adequate.

The haematocrit values that ranged from 41.61 to $41.93 \%$ were not significant. This was not different from the range of $37.7-42 \%$ recorded by Bleyere et al. [25] and also fell within the range of $29-44 \%$ reported by Byanet et al. [28] for grasscutters. This implies that, the nutritional adequacy of the diets was maintained despite the different feeding regimes adopted or that these feeding regimes had no adverse effect on this blood parameter studied.

Erythrocyte indices determined namely; Mean Corpuscular Volume (MCV), Mean Corpuscular Haemoglobin (MCH) and Mean Corpuscular Haemoglobin Concentration (MCHC) revealed no significant $(\mathrm{p}>0.05)$ difference between treatments. These parameters were to help evaluate whether experimental grasscutters suffered anaemia consequent upon the administration of the different feeding regimes. The MCV values obtained in the study were higher than the range of values $(55.8-55.90 \mathrm{fl})$ recorded by Bleyere et al. [25]. The $\mathrm{MCH}$ values $25.35-25.90 \mathrm{pg}$ was also higher than values 
(18.7-19.9 pg) obtained by Bleyere, et al. [25]. In contrast to $\mathrm{MCHC}$ in this study the values range obtained (28.10-28.45 $\mathrm{g} / \mathrm{dl})$ was lower than 33.6-34.4 (g/dl) reported by Bleyere et al. [25]. The $\mathrm{MCH}$ and $\mathrm{MCHC}$ are respectively defined as the contained amount of haemoglobin in a red blood cell and average concentration of haemoglobin in the cells. They are related to haematocrit and red blood cell count so they occupied volume by them in a specified volume of blood [29]. This reflects their change when the volume of blood sample is increased. Other factors such as stress, explains modification of both haematological parameters. Grasscutters, according to some studies, are very sensitive animals to the environment so their haematological studies can vary [30]. Normal values of $\mathrm{Hb}, \mathrm{PCV}, \mathrm{RBC}, \mathrm{MCH}, \mathrm{MCV}$ and $\mathrm{MCHC}$ could be related to nutritional adequacy and safety of the test ingredients [31]. Lindsay [32] reported that, reduction or abnormal values of $\mathrm{Hb}$, $\mathrm{PCV}, \mathrm{RBC}, \mathrm{MCH}, \mathrm{MCV}$ and $\mathrm{MCHC}$ may indicate a low protein intake or liver damage, anaemia, or parasitological infection. This however, did not occur to the grasscutters in this study which may invariably mean that, the concentrate diet were balanced and well-fortified to supply adequate nutrients with minerals and vitamins supplement.

Nothing out of the ordinary was observed for the parameters like, leucocytes, lymphocytes, neutrophil and eosinophil counts in this study. Leucocytes values are comparable to the values $\left(3-4 \times 10^{6} / \mu \mathrm{l}\right)$ observed by Olomu et al. [24] but less than 7.2-95 x 10\% $/ \mu 1$ and $10.44 \times 10^{6} \mu 1$ reported by Bleyere et al. [25] and Byanet et al. [28] respectively. Leucocytes counts may be altered by factors such as age, nutritional status, pregnancy and lactation [33]. Leucocytes counts have been reported to increase from any of these; stress, exercise, feeding, age, breed and wide variety of other conditions [34]. Other condition include, infection, stress of unfavourable conditions in the animal habitat, such as shortage of food and water [35]. In this study, it appears that, this adverse effect of any of those conditions were not encountered hence a lower leucocyte counts was observed. In this study, the lymphocytes values were less than the values of $38.8 \%$ to $61.7 \%$ reported by Bleyere et al. [25] however, it fell within the range of $27-46 \%$ earlier reported by Byanet et $a l$. [28] for healthy grasscutters. This is an indication that the feedingstufs (forage and concentrates) regimes did not introduce any foreign body to the system. In this present study, the lymphocytes counts are less than the neutrophil counts. This observation agreed with findings of Byanet et al. [28] for grasscutter and of schalm et al. [17] for cat and dog. However, it differs in human [36] Donkey Nayer, [37], goat, sheep, cattle and pig Schalm et al. [17] where lymphocyte counts were much higher than the neutrophils. In this study, monocytes values were not observed which agrees with Olomu et al. [24] observation but disagreed with Byanet et al. [28] who recorded $1.4 \%$.

Eosinophils and Basophils had values of $0.04-1.05 \%$ and $0.00 \%$ respectively. These values are in harmony with the values observed by Byanet et al. [28]. Eosinophils and Basophils play a role in regulatory allergic and inflammatory processes and host defense response against parasitic infections, like helminthiasis and ectoparasitic infection [34]. The mean of $1.00 \%$ for eosinophil cells was very low when compared to other animals 4, 5.5, 9, 5.0, 5 and 3.5\% for dog, cat, cattle, sheep, goat and pig respectively. The reason for the lowest eosinophil counts in grasscutters is yet to be known [28]. In this study, the basophilic cells were not observed. The basophilic cells have been reported to be rare in the blood [34].

In this study, the blood platelet had a significant value $(\mathrm{P}<0.05)$ as against the findings reported by Bleyere et al. [25] where they had no significant effect $(\mathrm{P}>0.05)$ in their study with grasscutters blood. This present study agrees with those results in rats (Rattus norvegicus) and the SpragueDawley rats $[38,39]$.

Table 3. Haematological parameters of Grasscutters fed different levels of concentrate supplement.

\begin{tabular}{|c|c|c|c|c|c|c|}
\hline Parameters & $T_{1}(1 \%)$ & $T_{2}(3 \%)$ & $T_{3}(5 \%)$ & $T_{4}(7 \%)$ & $T_{5}(9 \%)$ & SEM \\
\hline \multicolumn{7}{|l|}{ Red Blood cell count } \\
\hline Red blood cell $\times 10^{6} / \mu 1$ & 5.00 & 5.15 & 4.95 & 5.10 & 5.35 & 0.139 \\
\hline Haemoglobin $(\mathrm{g} / \mathrm{dl})$ & $12.07^{\mathrm{b}}$ & $12.25^{\mathrm{ab}}$ & $12.55^{\mathrm{a}}$ & $12.45^{\mathrm{ab}}$ & $12.55^{\mathrm{a}}$ & 0.121 \\
\hline Haematocrit (\%) & 41.90 & 41.70 & 41.93 & 41.61 & 41.90 & 0.339 \\
\hline \multicolumn{7}{|l|}{ Erythocyte Indices } \\
\hline MCV (fL) & 90.50 & 90.05 & 89.25 & 90.80 & 90.15 & 1.08 \\
\hline $\mathrm{MCH}(\mathrm{Pg})$ & 25.65 & 25.35 & 25.50 & 25.90 & 25.85 & 0.42 \\
\hline $\mathrm{MCHC}(\mathrm{g} / \mathrm{dl})$ & 28.35 & 28.20 & 29.20 & 28.10 & 28.45 & 0.39 \\
\hline \multicolumn{7}{|l|}{ Leukocyte Parameters } \\
\hline Leucocytes $\times 10^{6} / \mu 1$ & 2.55 & 2.55 & 2.55 & 2.55 & 2.50 & 0.089 \\
\hline Lymphocytes (\%) & 30.75 & 30.75 & 31.00 & 30.75 & 30.85 & 0.24 \\
\hline Monocytes (\%) & 0.00 & 0.00 & 0.00 & 0.00 & 0.00 & 0.00 \\
\hline Neutrophil (\%) & 56.15 & 55.97 & 55.65 & 55.60 & 55.57 & 0.46 \\
\hline Eosinophil (\%) & 0.99 & 1.05 & 1.04 & 0.98 & 0.04 & 0.044 \\
\hline Basophils (\%) & 0.00 & 0.00 & 0.00 & 0.00 & 0.00 & 0.00 \\
\hline \multicolumn{7}{|l|}{ Thrombocytes } \\
\hline Platelets $\times 10^{3} / \mu 1$ & $789.50^{\mathrm{a}}$ & $769.00^{\mathrm{ab}}$ & $762.50^{\mathrm{b}}$ & $782.00^{\mathrm{ab}}$ & $787.50^{\mathrm{ab}}$ & 6.93 \\
\hline
\end{tabular}

$a$, and $b$, means within rows with similar superscripts are not significantly different ( $p>0.05), S E M=$ Standard Error of mean,

\subsection{Serum Biochemical Variables}

The data on serum biological variables of grasscutter fed concentrate supplement feeding regimes are presented in Table 4.

For serum chemistry, the serum glucose levels in this trial was 
significant. The highest value was in $T_{5}$. This was expected because more concentrate was offered in the treatment which also led to high feed intake. It was also observed that there was no particular trend of increase of this glucose due to the percentage increase of concentrate supplement. However, several factors are indicators of this increase in glucose level and these are; age of the grasscutters which are correlated with the concentration of nutrients [40]. It could also be determined or influenced by the nutritional timing and methods of blood sample collection for the study [25].

Low blood glucose levels in micro livestock (rabbits) can also occur due to anorexia, starvation and disturbance in digestion [41]. However, the range of serum glucose level obtained for grasscutters in this study when compared to $137.63 \mathrm{mg} / \mathrm{dl}$ (Ogunsami et al. [26]) for captive reared, and 90-95 mg/dl (Opara et al. [227]; for wild grasscutters indicated that the animals were not surviving at the expense of body tissues. Generally, in carbohydrate rich diet, the carbohydrate is broken down in the gastrointestinal tract of ruminant and non-ruminant animals and absorbed into the blood as glucose. The glucose is then carried to liver where it is stored as glycogen. With the action of insulin only enough glucose is left in the blood for normal metabolism. Any depletion of carbohydrate reserve, either due to metabolism or insulin related disorder leads to breakdown of fat and protein as energy source. [42].

The value obtained was seen to be less than values observed $(137.63 \mathrm{mg} / \mathrm{dl})$ by Ogunsami et al. [26]; for captive reared, and $90-95 \mathrm{mg} / \mathrm{dl}$ for wild grasscutters Opara et al. [27] and $228-255.8 \mathrm{mg} / \mathrm{dl}$ reported by Bleyere et al. [25]. This disparities with other researchers may be attributed to the different types of diets with different nutrients content. This present study indicated that, there was a low level of energy in the diet given to this grasscutters when compared to the energy level given by Bleyere et al. [25] in their study.

The total protein level in this study varied from 4.49-4.95 $\mathrm{g} / \mathrm{dl}$ and did not differ significantly $(\mathrm{p}>0.05)$ and this could be the level for the animal's requirement since they was no sign of malnutrition. This probably implies that, the grasscutters were not under thermal stress, thus there was adequate total protein level in the serum. Kaneko [43] reported that, thermal stress caused an increase in adrenal activity resulting in increase in turn over, which leads to decrease in total serum protein. This however, did not occur in this experiment, as the total serum protein values were in consonance with the values that did not affect the grasscutters negatively. Total serum protein maintains osmotic balance between the circulatory blood and tissues spaces [43]. Total protein concentration is a measure of the diet consumed by livestock. Thus, from the total protein levels, it can be inferred that the various feeding regime diets contain adequate nutrients for the healthy growth of the growing grasscutters.

The globulin values obtained was significant $(\mathrm{p}<0.05)$ and it appears not to have any adverse effect on the parameters studied. This may imply that the values of serum globulin may be adequate for the grasscutters performance, an indication that, the feeding regimes did not adversely affect the nutritional status of the grasscutters.

The serum albumin values of $2.56-3.37 \mathrm{~g} / \mathrm{dl}$ obtained in this study were also significantly $(\mathrm{p}<0.05)$ different and since there was no indication of abnormalities in the grasscutters, it therefore implies that this range of values are appropriate for grasscutters. Abnormal high values of serum protein indicate liver disease and chronic enteropathy [41]. Starvation can also reduce serum protein levels, serum globulin and serum albumin values.

The serum cholesterol obtained varies from 99.59-112.10 $\mathrm{mg} / \mathrm{dl}$, it was significant and seen to be similar to 87-101 $\mathrm{mg} / \mathrm{dl}$ obtained by Bleyere et al. [25], but less than 126.4 $\mathrm{mg} / \mathrm{dl}$ for captive reared adult grasscutters and $197 \mathrm{mg} / \mathrm{dl}$ for wild grasscutters as reported by Ogunsami et al. [26], Opara et al. [27] respectively. The study revealed that, the feeding regimes in the grasscutters had no adverse effect. Thus, the experimental grasscutters were not vulnerable to coronary conditions which may result to ill health when the serum cholesterol is high, since values obtained are in consonance with the values by other researchers and even less.

The alanine- amino transaminase values obtained in this study which ranged from $19.70-36.66 \mu 1$ was significant and was comparable to the lower value range of 36.5-39.9 $\mu \mathrm{l}$ obtained by Bleyere et al. [25] while the aspartate- amino transaminase values ranged from 53.24-70.83 $\mu \mathrm{l}$ ) and was less than the values 122.5-132.3 ( $\mu \mathrm{l}$ ) obtained by Bleyere et al. [25]. These two enzymes are found in the tissues and mostly the liver. Their elevation above normal levels shows some pathological disorders in the liver and since both visual appearance and sizes of the livers were normal, it therefore suggested that, the values obtained in this study had no any adverse effect on the grasscutter livers since they are biomarkers of liver health which implies that the feeding regimes did not affect the grasscutters adversely,

The sodium value obtained in this study was significant and no particular trend was followed. This value obtained are comparable with the values 134-138.55 (mmol/l) obtained by Byanet et al. [28] and those of (140-153 mmol/l) reported by Bleyere et al. [25].

The potassium values obtained in this study 4.24-4.72 (mmol/l) was not significant but was comparable to values obtained by Byanet et al. [28], 3.8-4.9 mmol/1 and also similar to those obtained for adult wild and captive grasscutters Ogunsanmi et al. [26], Opara et al. [27] but less than the values 7.8-10 mmol/1 reported by Bleyere et al. [25].

The Chlorine values obtained in this study ranged from 91.89-98.48 $\mathrm{mmol} / \mathrm{l}$ and was significant and was also comparable to values of 84.1 - $108.8(\mathrm{mmol} / \mathrm{l})$ obtained by Byanet et al. [28] and also similar to those obtained for adult wild and captive grasscutters (Ogunsanmi et al. [26], Opara et al. [27] but less than the values of 103-111 (mmol/l) values obtained by (Bleyere et al. [25].

Generally, the Serum biochemical variables in this study revealed that all the parameters studied appears to be normal. Since the values obtained for visceral organs weight were normal and comparable to other researchers which confirms that the results of this experiment were within the normal 
values for grasscutters. It is a common practice in feeding trials to use weights of the visceral organs like liver, kidney etc. as an indicator of toxicity. Bone [44] reported that, if there is any toxic element in the feed, abnormalities in weight of liver and kidney would be observed.

The abnormalities will arise because of increased metabolic rate of the organs in attempt to reduce those toxic elements or anti-nutritional factors to non-toxic metabolites. Since these abnormalities did not occur, it implies that these feeding regimes adopted supplied adequate nutrients to meet the nutritional requirements of grasscutters for tissue accretion.

Table 4. Serum biological variables of grasscutters fed different levels of concentrate supplement.

\begin{tabular}{|c|c|c|c|c|c|c|}
\hline Biochemical parameter. & $T_{1}(1 \%)$ & $T_{2}(3 \%)$ & $T_{3}(5 \%)$ & $T_{4}(7 \%)$ & $T_{5}(9 \%)$ & SEM \\
\hline \multicolumn{7}{|l|}{ Glycoside } \\
\hline Glucose (mg/dl) & $73.77^{\mathrm{b}}$ & $69.35^{\mathrm{b}}$ & $59.12^{\mathrm{c}}$ & $73.91^{\mathrm{b}}$ & $87.73^{\mathrm{a}}$ & 2.95 \\
\hline \multicolumn{7}{|l|}{ Protein } \\
\hline Total protein $(\mathrm{g} / \mathrm{dl})$ & 4.95 & 4.51 & 4.49 & 4.53 & 4.61 & 0.22 \\
\hline Globulin (g/dl) & $1.97^{\mathrm{a}}$ & $1.85^{\mathrm{a}}$ & $1.83^{\mathrm{a}}$ & $1.71^{\mathrm{ab}}$ & $1.12^{\mathrm{b}}$ & 0.20 \\
\hline Albumin (g/dl) & $3.10^{\mathrm{ab}}$ & $2.83^{\mathrm{ab}}$ & $3.37 \mathrm{a}$ & $2.56^{\mathrm{b}}$ & $2.78^{\mathrm{ab}}$ & 0.21 \\
\hline \multicolumn{7}{|l|}{ Lipids } \\
\hline \multicolumn{7}{|l|}{ Enzymes } \\
\hline Alanine-Transaminase $(\mu \mathrm{l})$ & $20.43^{c}$ & $27.09^{\mathrm{b}}$ & $28.53^{b}$ & $19.70^{\mathrm{c}}$ & $36.66^{\mathrm{a}}$ & 1.56 \\
\hline AspartineTransaminase $(\mu 1)$ & $53.24^{\mathrm{b}}$ & $55.80^{\mathrm{b}}$ & $70.83^{\mathrm{a}}$ & $59.84^{\mathrm{b}}$ & $58.03^{\mathrm{b}}$ & 2.14 \\
\hline \multicolumn{7}{|l|}{ Ions } \\
\hline Sodium $(\mathrm{mmol} / \mathrm{l})$ & $136.87^{\mathrm{bc}}$ & $131.73^{\mathrm{bc}}$ & $155.66^{\mathrm{a}}$ & $127.97^{\mathrm{c}}$ & $148.25^{\mathrm{ab}}$ & 5.29 \\
\hline Potassium (mmol/l) & 4.61 & 4.72 & 4.54 & 4.49 & 4.24 & 0.32 \\
\hline Chlorine $\mathrm{mmol} / \mathrm{l}$ ) & $94.55^{\mathrm{ab}}$ & $98.48^{\mathrm{a}}$ & $92.85^{b}$ & $93.14^{\mathrm{b}}$ & $91.89^{b}$ & 1.53 \\
\hline
\end{tabular}

$\mathrm{SEM}=$ Standard Error of mean,

\section{Conclusion}

It was observed that, none of the haematological and serum biochemistry values measured showed any threat to the health of the grasscutters, an indication of nutritional adequacy and safety level of the different feeding regimes. Based on these observations, it was therefore concluded that, concentrate supplement feeding regime particularly that of feeding $5 \%$ of their weekly body live weight using elephant grass as basal feed can be used to feed grasscutters without any adverse effect on their health or physiological activities.

\section{References}

[1] FAO. 2000. World Watch List for Domestic Animal Diversity (p 716). Retrieved r from ftp://ftp,fao.org/docrep/fao/009/x8750e03.pdf

[2] Karikari P. K. and Nyameasem, J. K. 2009. Productive performance and carcass Characteristics of captive grasscutters (Thryonomys swinderianus) fed concentrate diets containing various levels of guinea grass. World Applied Science Journal, 6 (4), 337-363

[3] Gbolagada S. A. 2008. Grasscutter/Cane rat farming in the tropics. University of Ibadan Press, Ibadan, Nigeria.

[4] Addo, P. G. 1997. Domesticating the Wild Grasscutter (Thryonomys swinderianus Temminck, 1827) under laboratory conditions. Ph. D Thesis, University of Ghana Legon, Accra, Ghana, pp: 245.

[5] Akinloye A. P. 2005. Update on grasscutter rearing. Thryonomys swinderianus (Temminck), Height mark printers, Ibadan, Nigeria, Pp 21-23.
[6] Opara M. N. and Fagbemi B. O. 2009. Dietary influences of feed types on the haematological Indices of captive-reared grasscutters experimentally infected with Trypanosoma congolence, proceeding of the $10^{\text {th }}$ Biennial conference of the society for Tropical Veterinary Medicine, June 28 - July 3, Lubeck. Germany, pp: 63-67.

[7] Afolabi K. D. Akinsoyinu A. O., Olajide R., Akinleye S. B. 2010. Haematological parameters of the Nigerian local grower chickens fed varying dietary levels of palm kernel cake (p. 247). Proceedings of 35th Annual Conference of Nigerian Society for Animal Production.

[8] Oke U. K., Herbert U., Ebuzoeme C. O. and Nwachukwu E. N. 2007. Effect of genotype on the haematology of Nigerian local chickens in humid tropical environment. Proc of 32nd Annual Conf of the Nig Soc for Anim Prod. 18 - 21.

[9] Maxwell M. H., Robertson G. W., Spence S. and Mc Corquodate C. C. 1990. Comparison of haematological values of restricted and ad libitum feeding in domestic fowl, Blood characteristics. Brit. Poult. Scl. 31 (3): $407-413$

[10] Adamu S., Thomas A., Iseh N. M., Fatihumi M. Y and Esieno K. A. N. 2006. Normal values of haematology of Nigeria adopted albino rats (Rattus norvegicus) in Zaria. Proc of the 31 st Annual Conf of Nig Soc for Anim Prod (NSAP).

[11] Togun V. A., Farinu G. O., Oyebiyi O. O., Akinlade J. A., Ajibok H. O. and Olaniyonu B. I. 2007. Comparative study of the effect of dietary replacement of $15 \%$ maize offal with pigeon pea (Cajanus cajan) grain or leaf meal on performance of weaners, rabbits. Proc of 32nd Annual Conf of the Nig Soc for Anim Prod. 217 - 219.

[12] Ameen S. A., Adedeji O. S., Akingbade A. A., Olayemi, T. B., Oyedapo L. O and Aderinola A. 2007. The effect of different feeding regimes on haematological parameters and immune status of commercial broilers in derived Savannah zone of Nigeria. Proc. of 32 Annual Conf. of the Nig Soc for Anim Prod. (NSAP) $146-148$. 
[13] Adekoya A. Y., Ayo A. Y., Sackey A. K. B. and Adelaiye A. B. 2008. Haematological changes in pigs administered with ascorbic acid and transported by road for four hours during the harmattan season. Proc of 42nd. Annual Conf. of the Agric Soc. of Nig. 2008: $659-663$.

[14] Ladokun A. O., Yakubu A., Otite J. R, Omeje J. N, Sokunbi O. A and Onyeji E 2008. Haematological and Serum biochemical indices of Naked and Normally feathered Nigerian Indigeneous Chicken in the Sub-Humid Tropical Environment. Intl J. of Poult. Sci. 7 (1): 55 - 58 ISSN 1582 8356. Asian Network of Scientific Information.

[15] Bush B. M. 1991. Interpretation of Laboratory Results for Small Animal Clinicians, Backwell Scientific Publications, London, ISBN: 9780408108492, Pp: 515

[16] Jain N. C. 1986. Schalm Veterinary Haematology. 4th ed., Lea and Febiger Philadelphia, USA

[17] Schalm O. W., Jain, N. C. and Caroll, E. J. 1975. Veterinary haematology, $3^{\text {rd }}$ Edition, Philadelphia (USA), Lea and Febiger $807 \mathrm{pp}$

[18] Dacie J. V. and Lewis S. M. 1991. Practical Heamatology. $7^{\text {th }}$ edn, Livinton, (ELBS) Church Hill Publishers. Pp 4: 6-7.

[19] Kelly W. R. 1979. Veterinary Clinical Diagnosis. $2^{\text {nd }}$ edn, London, Bailliere Tindall Publishers. Pp 4: 6

[20] Smith P. K. 1985 Measurement of protein using bicinchoninic acid, Anal. Biochem 150: 75-85.

[21] Kusi C., Tuah, A. K., Annor S. Y. and Djang-Fordjour K. T. 2012. Determination of dietar Crude protein level required for optimum growth of the grasscutter in captivity. Livestock Research for Rural Development, 24 (10) http://www.irrd.org/irrd24/10/kusi241

[22] Onyeanusi A. E., Akinola O. O. and Babadoye A. O. 2008. Performance of grasscutte (Thryonomys swinderianus) fed Varying Levels of Dietary Protein. Journal of Innovation and Development Strategy, 2 (3): 1-4.

[23] Wogar G. S. I., Umoren U. E. and Samson R. M. A. 2007. Effect of Legume forage on performance of growing grass cutters fed cassava-based energy and protein diets. Proceeding of the Annual Conference of the $32^{\text {nd }}$ Nigerian Society for Animal Production (NSAP); $18^{\text {th }}-21^{\text {st }}$ March, 2007 at the University of Calabar. Pp 56.

[24] Olomu J. M., Ezieshi V. E. and Orheruata A. M. 2003. Grasscutter Production: Principles and Practice. A Jachem Publication, Benin, Nigeria. Pp 8: 67

[25] Bleyere M. N., Mensah S. E. P., Pomalegai C. B., Fantodji, A. T. and Mensah G. A. 2013. Period and Repeatability of Blood Sampling in Reared Grasscutter (Thryonomys Swinderinus Temminck. 1827) in Benin. Journal of Animal Production Advances, 3 (4): 144-157.

[26] Ogunsanmi A. O., Ozegbe P. O., Ogunjobi O., Taiwo, V. O. and Adu, J. O. 2002. Haematological, plasma biochemistry and whole blood minerals of the captive adult African grasscutter (Thryonomys swinderianus Temminck). Tropical Veterinary 20 (1) 27.

[27] Opara, M. N., Ike, k. A. and Okoli, I. C. 2006. Haematology and Plasma Biochemistry of the wild Adult African Grasscutter (Thyronomys swinderianus, Temminck). Journal of Animal Science 2 (2): 17-22
[28] Byanet O., Adamu S., Salami S. O. and Obadiah H. L. 2008. Haematological and Plasma Biochemical parameters of the young grasscutter (Thyronomys swinderianus) northern Nigeria. Journal of cell and Animal Biology vol. 2 (10). Pp, 177-181

[29] Williams W. J. 1983. Examination of blood. In: Haematology. Williams W. J Beutler E, Erslev A. J., Lichtman M. A Ed. McGraw-Hill. New York, $3^{\text {rd }}$ ed P. 9

[30] Mensah G. A., 1997. Ecoethology of the grasscutter (Thryonomys swinderianus (Termminck 1827) rodent hystricomorphe, Bulletin Rech Agro (Benin) 17: 19-31. [In French]

[31] Olabanji R. O., Ojebiyi O. O., Tona G. O. and Olaogun O. 2007. Haematological and serum biochemical response of growing rabbits fed diets containing Mango (Mangifera indica) seed kernel Meal. Proc. of 14th Ann. Conf.

[32] Lindsay D. B. 1977. The effect of feeding patterns and sampling of blood parameters. British Journal of Nutrition. 56: 99-120.

[33] Reece W. O. 1997. Physiology of Domestic Animals. Williams and Wilkins New York. Pp 67.

[34] Dellmann H. and Brown E, M. 1987. Blood and bone marrow. In: Textbook of Veterinary Histology, $3^{\text {rd }}$ Ed Lea Fibiger, and Philadelphia pp. 71-85.

[35] Goto S., Takennako O. Watanabe k. Kawatomo R., Watanabe T. Surgobroto B. and Sajuthi O. 1987. Haematological values and parasitic fauna in freed ranged macaca tonkeuna/ Macaca hecki hybrid group of salawei island; Indonesia primates $\mathrm{Pp}$ 42: 27.

[36] Ezeilo G. C. and Obi G. O. 1989. Neutropenia in apparently healthy humans. Nigerian Journal Physiology Science 1: 1-6.

[37] Nayer G. D. 1978. Blood characteristics of the adult donkey. Zentrablatt Veterinarmed. 25: 241-547.

[38] Rowan A. N. 1989. Biological effects of blood loss: implication for sampling volumes and Techniques. ILAR New 31: $5-20$

[39] Descat F. 2002. Hematologie du rat: hemogramme et myelogramme. Memoire de Doctoral de Medicine veterinaire a I'Ecole National Veterinaire de Toulouse/France. p 109.

[40] Serrano E., Gonzalez F. J., Granados J. E., Moco D. G., Fandos P. Soriguer R. C. and Perez. J. M. 2008. The use of total serum proteins and triglycerides for monitoring body Condition in the Iberian Wild goat (Capra pyrenaica). Journal zoo Wildlife Medicine. 39 (4): 646-649.

[41] Mitruka B. M. and Rawnsley H. 1977. Clinical Biochemistry and Haematological. Reference values in National Experimental Animals. $1^{\text {st }}$ Edition, New York, USA. Masson Publishing Inc. PP. 106-112.

[42] Ahamefule F. O., Edouk G. O., Usman A., Amaefule K. U., Odua B. E. and Oguike, S. A (2006). Blood chemistry and haematology of weaner rabbits fed sun dried, ensiled and fermented Cassava peel based diets. Pakistan Journal of Nutrition 5 (3): 248-253.

[43] Kaneko J. J. 1989. Clinical Biochemical of Domestic Animals, 4th Edn, London academy Press Ltd. Pp 495-498.

[44] Bone F. J. 1979. Anathomy and Physiology of Farm Animals. $2^{\text {nd }}$ edn. Reston pub. Comp. inc. Virginia USA. Pp 560. 